\title{
PERANAN APARAT SYARA' DALAM GERAKAN KELUARGA BERENCANA DI KECAMATAN BANGGAE KAB. MAJENE
}

\section{Oleh : ABUBAKAR SURUR}

\section{PENDAHULUAN}

\section{LATAR BELAKANG MASALAH}

Dalam Garis - Garis Besar Haluan Negara Tahun 1988 dinyatakan, bahwa "Pengendalian pertumbuhan penduduk terutama dilakukan melalui upaya penurunan tingkat kelahiran dan keraatian, khususnya kematian bayi dan anak. Penurunan tingkat kelahiran terutama dilakukan dengan gerakan keluarga berencana, yang juga bertujuan meningkatkan kesejahteraan ibu dan anak, dalam rangka mewujudkan keluarga kecil, bahagia dan sejahtera (GBHN : 1988).

Lebih lanjut dinyatakan, bahwa "Peranan dan tanggungjawab dalam rangka gerakan keluarga berencana, baik perorangan maupun masyarakat, perlu makin didorong dan diperkuat dengan semakin melibatkan organisasi dan pemuka masyarakat serta pihak-pihak swasta, sehingga pengelolaan dan pelaksanaan keluarga berencana dapat semakin meningkat".

Berbagai upaya yang dilakukan oleh lembaga resmi pengelola keluarga berencana selama ini, untuk merangsang kegairahan dan keikutsertaan masyarakat dalam rangka kesuksesan pelaksanaan gerakan keluarga berencana, antara lain mendorong dan memberikan peran yang lebih nyata pada potensi yang ada dalam masyarakat untuk turut serta mengambil peranan yang sesuai dengan bidangnya, melalui institusi yang ada berkembang pada masyarakat tersebut, serta memberikan dukungan dan pengayoman kepada instansi masyarakat untuk menjadi wadah kegiatan masyarakatnya sendiri melalui berbagai kegiatan.

Khusus di Sulawesi Selatan, berbagai kegiatan yang dianggap sebagai terobosan, telah dilakukan oleh $\mathrm{BKKBN}$, antara lain dalam kegiatan peningkatan peran serta kaum wanita, pemuda, mengadakan temu wicara dengan unsur-unsur yang terlibat dalam gerakan keluarga berencana, memanfaatkan lembaga tradisional masyarakat, dalam rangka memasyarakatkan keluarga berencana, dan kegiatan lainnya, baik secara terpadu maupun secara sektoral. Hasil dari kegiatankegiatan itu cukup berarti dalam meningkatkan persentase pencapaian target peserta KB baru dan pembinaan peserta KB aktif.

Namun dibalik keberhasilan itu, terdapat hal-hal yang kurang menggembirakan, antara lain rendahnya proporsi pemakai kontrasepsi efektif terpilih dibandingkan dengan kontrasepsi lain. Hal ini disebabkan oleh beberapa faktor, terutama yang berkaitan dengan budaya dan kepercayaan serta keyakinan masyarakat, misalnya rasa malu, khususnya yang berkaitan dengan pemasangan IUD pada alat vital wanita.

Selain dari itu, faktor panutan masyarakat, terutama di pedesaan, enggan menerima sesuatu yang baru, sebelum orang yang menjadi panutan mereka menerimanya.

Faktor-faktor tersebut di atas, 
berpengaruh terhadap suksesnya pelaksanaan gerakan KB di Sulawesi Selatan. Karena itu perlu dicari dan diupayakan terus untuk menemukan cara-cara yang dipandang efektif menerobos kendala dalam masyarakat. Salah satu upaya ialah memanfaatkan pranata sosial keagamaan yang secara tradisional tumbuh dan berakar kuat dalam kehidupan masyarakat, seperti halnya syara'.

Syara' adalah salah satu institusi keagamaan khas masyarakat Sulawesi Selatan, yang peranannya sangat memasyarakat. Aparat syara' adalah aparat yang paling akrab berhub-mgan dengan masyarakat, untuk melayani kepentingan mereka baik yang* menyangkut urusan sosial keagamaan maupun ibadah. Apabila syara' difungsikan dan dilibatkan langsung dalam kegiatan pelaksanaan gerakan keluarga berencana, akan sangat membantu suksesnya pelaksanaan dan pencapaian target keluarga berencana tersebut di daerah ini. Seberapa jauh keterlibatan aparat syara' dalam menunjang gerakan keluarga berencana di berbagai daerah di Sulawesi Selatan, belum terungkap dengan jelas.

Untuk keperluan itulah, penelitian "Peranan Aparat Syara' dalam Gerakan Keluarga Berencana di kecamatan Banggae Kabupaten Majene ", dilaksanakan.

\section{TUJUAN DAN KEGUNAAN PENE- LITIAN.}

Penelitian ini dilakukan dengan tujuan untuk mengetahui kemungkinan pemanfaatan syara' untuk menunjang kesuksesan gerakan keluarga berencana nasional, khususnya di Majene, Sulawesi Selatan. Tujuan tersebut, lebih lanjut dibagi 2 tujuan khusus, yaitu : 1) Memperoleh informasi tentang fungsi syara' dan peranannya sebagai lembaga sosial keagamaan masyarakat, dan 2). Mendapatkan informasi kemungkinan pemanfaatan aparat syara' sebagai penunjang suksesnya pelaksanaan gerakan keluarga berencana.

Hasil penelitian ini diharapkan dapat memberikan sumbangan bermakna bagi pengembangan ilmu dan menambah khazanah disiplin ilmu terkait yang dapat bermanfaat untuk memecahkan masalahmasalah sosial yang terdapat dalam masyarakat.

\section{METODOLOGI}

Penelitian ini dilaksanakan di Kecamatan Banggae Kabupaten Majene, sebagai salah satu daerah komunitas Mandar, dengan mengutamakan imam kelurahan dan aparat syara' lainnya sebagai sarana.

Untuk memperoleh data, peneliti menggunakan observasi langsung dan observasi partisipasi, disamping menggunakan teknik wawancara mendalam dengan menggunakan pedoman wawancara, panduan tugas lapangan dan kuesioner.

Teknik lainnya adalah studi pustaka dan penelusuran dokumentasi.

Selain dengan responen (aparat syara'), peneliti melakukan juga wawancara dengan tokoh masyarakat, pemuka agama serta pejabat instansi yang terkait, di lokasi penelitian.

Data yang terkumpul, diolah dan dianalisis dengan analisis kualitatifkualitatif, kemudian disusun laporan hasil penelitian.

\section{LOKASI PENELITIAN}

Kecamatan Banggae, Kabupaten Majene, Sulawesi Selatan, terletak di

No. 11 Th. VI Juti/Desember 1994 
kawasan pantai, memanjang dari luar pada batas Kabupaten Polmas, ke barat pada batas Kecamatan Pamboang, Kabupaten Majene, dan diapit oleh Teluk Mandar di sebelah selatan dan bukit di sebelah utara. Kecamatan Banggae memiliki alam yang indah dan pemandangan yang menarik, apalagi jika kita berada di tempat ketinggian semakin nampak keindahannya yang alami, yang merupakan bagian dari keindahan alam di Sulawesi Selatan.

Sebagai kawasan pantai yang diapit gunung dan laut, maka tanah persawahan hampir tidak ditemukan, sehingga beras di datangkan dari daerah tetangga.

Tanah perkebunan hasil utamanya adalah kelapa, kopi dan coklat dan merupakan komoditi masyarakat. Disamping hasil tanaman, sebagian kecil penduduk memelihara hewan ternak, unggas dan tambak.

Di sektor industri, diantara masyarakat ada yang bergerak di bidang kerajinan kayu dan rotan dan usaha produksi minyak kelapa. Kaum wanita bergerak dalam usaha tenun sutera yang dikenal dengan sarung mandar yang banyak dipasarkan di luar Sulawesi Selatan, terutama di Sumatera Barat, Riau, Kalimantan Timur dan Jakarta.

Batas - batas Kecamatan Pamboang, sebelah timur Kecamatan Tinambung, Polmas, sebelah selatan Teluk Mandar dan sebelah barat Selat Makasar.

Kecamatan Banggae terdiri dari 5 kelurahan, masing-masing :

1) Kelurahan Banggae, 2) Labuang, 3) Totoli, 4) Baruga 5) Kelurahan Tande.

Jumlah penduduk 54.901 Jiwa, terdiri dari laki-laki 26.723 orang dan wanita 28.178 orang. Perincian dapat dilihat dalam tabel berikut :
Jumlah penduduk Kecamatan Banggae, Tahun 1989:

\begin{tabular}{lccr} 
No. Kelurahan & Laki-laki & Wanita & \\
\hline 1. Banggae & 8.141 & 8.545 & 16.686 \\
2. Labuang & 8.050 & 8.570 & 16.620 \\
3. Totoli & 6.314 & 6.477 & 12.791 \\
4. Tande & 1.834 & 2.031 & 3.865 \\
5. Baruga & 2.384 & 2.555 & 4.939 \\
\hline & & & \\
Jumlah & 26.723 & 28.278 & 54.901
\end{tabular}

Sumber : Registrasi Penduduk (Mantri Statistik) Banggae.

\section{KEHIDUPAN BERAGAMA}

Penduduk asli Kecamatan Banggae terdiri dari Suku Mandar yang seluruhnya penganut Islam yang taat, sedang agama lain dianut oleh pendatang. Penganut agama di Kecamatan Banggae terdiri dari : Agama Islam 54.711 orang, Katholik 37 orang. Kristen 153 orang, dan Hindu 3 orang. Non Islam tersebut di atas adalah Suku Toraja dan Jawa.

Sarana pendidikan di Kecamatan Banggae terdiri dari sekolah umum dan Madrasah, mulai dari Taman Kanak-kanak sampai perguruan tinggi. Keadaan sarana pendidikan dapat dilihat pada tabel berikut :

$$
\text { Jumlah Saranan Pendidikan di }
$$
Kecamatan Banggae Tahun 1989 adalah sbb :

\section{A. Sekolah Umum, beijumlah 93 buah terdiri dari :}

1. Taman Kanak-kanak 17

2. SD Negeri/SD Inpres

65 

3. SMTP Negeri
5
4. SMTA Negeri/Swasta
6

B. Madrasah sebanyak 25 buah, terdiri dari :

1. Ibtidaiyah Negeri/Swasta

2. Tsanawiyah Swasta

3. Aliyah Swasta

C. Perguruan Tinggi, tiga buah, masing2 :

IAIN, Fak. Syariah Cab. Majene, Sekolah Tinggi Ilmu Administrasi dan Sekolah Tinggi Ilmu $\mathrm{T}^{\wedge}$ rbiyah.

Sarana Ibadah di Kecamatan Banggae milik umat Islam berupa Masjid dan mushalla berjumlah 81 buah terbesar di lima kelurahan, sedangkan gereja milik Kristen terdapat 1 buah di Kelurahan Labung. Untuk jelasnya dapat dilihat dalam sebagai berikut :

\section{Keadaan Tempat Ibadah di Kecamatan Banggae Tahun 1989 :}

No. Kelurahan Masjid Mushalla Gereja Jumlah

\begin{tabular}{|c|c|c|c|c|}
\hline 1. Totoli & 11 & .7 & & 18 \\
\hline 2. Banggae & 10 & 9 & & 19 \\
\hline 3. Labuang & 13 & 7 & 1 & 21 \\
\hline 4. Tande & 8 & 2 & & 10 \\
\hline 5. Baraga & 7 & 7 & & 14 \\
\hline Jumlah & 49 & 32 & 1 & 82 \\
\hline
\end{tabular}

Sumber: KUA Banggae, Th. 1989.

Penduduk Kecamatan Banggae adalah penganut Agama Islam'yang teguh melaksanakan ajaran agamanya. Segala aspek kehidupan seperti perkawinan, kelahiran, mendirikan dan menaiki rumah baru, turun sawah dan kegiatan daur hidup lainnya, dilakukan dan diwarnai dengan rirual keagamaan, yang dipadukan dengan tradisi.

Dilihat dari sesi sejarah, Islam diperkenalkan pertama kali oleh Syekh Abdul Manan, yang berasal dari Gowa. Kedatangannya di kerajaan Banggae di perkirakan pada pertengah abad ke 17 Syekh Abdul Manan memperkenalkan Islam kepada rakyat Banggae, melalui pusat kerajaan, dengan terlebih dahulu membujuk putra mahkota Kerajaan yang bernama "Daeng Tamelanto" untuk dijadikan tonggak penyebaran Islam di kerajaan Banggae. Syekh Abdul Manan berhasil mengajak Daeng Tamelanto memjsluk Islam dan mendorong untuk membentuk wadah ulama yang digabung dalam Kelompok Tujuh, tiga orang diantaranya yang sangat populer yaitu Syekh Abdul Manan, Daeng Tamelanto dan Tuanta di Culang.

Lontarak Kerajaan Banggae menyebutkan, bahwa sementara Baginda Raja memimpin pertemuan Dewan Kerajaan, datang orang menghadap kepadanya, termasuk Daeng Tamelanto maka diperintahkan Angongguru Totangloa memanggil tamu tersebut. Maraddia Banggae gembira setelah melihat diantara yang datang itu adalah Daeng Tamelanto karena yang akan dibicarakan adalah mengenai penggantian raja, sedang Daeng Tamelanto adalah putra mahkota yang baru saja kembali dari Gresik, Jawa Timur belajar Islam disana.

Daeng Tamelanto bersedia dengan syarat : 1) selain menjadi Maraddia, ia juga merangkap jabatan "Pabbicara" di Totoli, sekaligus menjadi qadhi kerajaan Banggae. 2) Maraddia Banggae yang 
(ayahandanya) merestui pembangunan masjid di Salabose, sebagai masjid Kerajaan Banggae. 3) Akan mengangkat seorang Imam atas nama Maraddia dan menempatkan di Totoli. Ketiga syarat tsb dikemukan oleh Daeng Tamelanto, agar dengan mudah mengislamkan rakyat Totoli dan Banggae.

Permintaan itu diterima oleh Raja Banggae, kemudian pelantikan Maraddia Baru yaitu Daeng Tamelanto segera dilakukan bersamaan dimulainya pembangunan masjid kerajaan di Salabose. Masjid tersebut masih utuh sampai sekarang dengan nama "Masjid Syekh Abdul Manan".

Syekh Abd. Manan selanjutnya mengislamkan penduduk Baruga dan Tande yang dipusatkan di Salebose dan Sallobo. Dengan demikian tersebarlah agama Islam di daerah-daerah Mandar.

Dalam rangka membina kegairahan beragama dan mengembangkan syiar Islam dewasa ini, beberapa organisasi Islam dibentuk sebagai alat untuk menumbuhkan jiwa keagamaan, dengan kegiatan difokuskan pada kegiatan sosial dan keagamaan. Adapun organisasi yang bergerak dibidang dakwah dan pendidikan Islam, adalah Nahdatul Ulama. Muhammadiyah, Majlis Dakwah Islamiyah, GUPPI, Darud Dakwah Wal Irsyad dan Alhidayah. Organisasi tersebut melakukan pengajian rutin, majlis taklim, acara-acara keagamaan dan peringatan hari-hari besar Islam. Bahkan ada arisan kaum wanita diisi dengan pengajian dan dakwah islamiyah, bekerjasama dengan organisasi Islam tersebut.

\section{IH. EKSISTENSIINSTITUSI SYARA}

Ketika Daeng Tamelanto memegang tampuk kerajaan di bentuk satu lembaga yang mengurus masalah keagamaan dengan segala aspeknya, yang dinamakan syara'. Seperti halnya kerajaan-kerajaan lainnya di Sulawesi Selatan yang menganut sistem pangadereng (Bugis) atau pangadakkang (Makassar), di Kerajaan Banggae (Mandar) syara' dimasukkan salah satu unsur adaq. Syara' sebagai lembaga dipimpin seorang qadhi (Kali) yang digelar "Maraddia Syara' ". Daeng Tamelanto sebagaia raja Banggae merangkap juga sebagai qadhi Banggae dibantu oleh perangkat syara' yang terdiri dari iman, khatib, bilal dan doja.

Keterkaitan antara adaq dan syara' disebutkan dalam lontara sebagai berikut :

Bainemi saraq muannemi adaq. Adaqmo maande cuke sara'mo maande pittara. Naiyya ingganna nabicara adaq, Ingganna toitia naissang saraq. Naiyya saraq adaq nala gassing, naiyya adaq saraq nala sulo. Matel adaq muandiang saraq matetoitia saraq muandiang adaq.

Artinya Syara' dianggap wanita dan adaq dianggap pria. Adaq wewenangnya dibidang cukai, syara' urusannya zakat pitrah. Wewenang adaq tidak dicampuri syara', wewenang syara' tidak diurusi adaq. Kekuatan syara' adalah adaq, adaq bersandar pada syara' dan syara' tidak berarti tanpa adaq.

Lembaga syara' diberikan fasilitas dan beberapa dispensasi. Syara' duduk berdampingan dengan adat, Kadhisebagai maradia syara' ke dalam pangadereng sejak Islam menjadi agama kerajaan, dapat dilihat pada pengangkatan seorang pemangku kerajaan ketika dinobatkan menjadi raja, didahului pengucapan sumpah yang dilakukan oleh maraddia

No. 11 Th. VI Juli/Desember 1994 
syara. Naskah sumpah adalah sebagai berikut :

"Mapparentami mandar sallami paqbanua sallang tomapparenta, diango tasallang miolo dipuanga anna damo muwata-watai, nasaba iamotuu ditingo nawalimi paqbanua, mapparentamoo paqbanua, tapi mua salao diditotuu malaii". Artinya : Mulailah memerintah kerajaan Mandar rakyatnya yang beragama Islam yang bertaqwa kepada Tuhan, maka janganlah ragu-ragu karena itulah yang menjadi pegangan. Maka jawablah oleh rakyat, tetapi apabila raja melakukan kesalahaan, maka akan diusir.

Syara' pada masa kerajaan lokal sampai masa penjajahan tetap diakui sebagai lembaga yang berdampingan dengan adaq, dan qadhi menjalankan fungsinya sebagai pemangku syara', karena urusan keagamaan tetap diberikan kepada institusi syara'.

Setelah kemerdekaan, maka fungsi syara banyak diintegrasikan kedalam struktur pemerintahan, terlebih lagi setelah terbentuk Departemen Agama pada tanggal 3 Januari 1964, maka berbagai masalah keagamaan ditangani, seperti urusan nikah, talak, cerai dan rujuk (NTCR) diurusi kantor Urusan Agama, kewarisan ditangani oleh Pengadilan Agama, pendidikan agama dikelolah oleh pendidikan agama Dep. Agama dan madrasah dibina oleh Perguruan Agama Dep. Agama.

Namun, peranan aparat syara' dalam menangani permasalah kehidupan masyarakat masih dominan, dan perhatian masyarakat terhadap institusi syara' masih besar.

\section{Fungsi Syara'}

Pada masyarakat Kecamatan Banggae, upacara-upacara tradisional masih mewarnai berbagai kegiatan daur hidup mereka. Keterkaitan antara adat dan syara' masih sukar dipisahkan, seperti pada upacara sosial keagamaan (aqiqa, perkawinan, syukuran, selamatan, dan semacamnya). yang pada umumnya dilaksanakan oleh syara'. Keterlibatan syara' dalam upacara tradisional dan keagamaan mutlak adanya, sehingga setiap keluarga yang akan melakukan hajat, harus lebih dahulu meminta kesediaan syara' barulah ditentukan waktu pelaksanaannya.

Kemakmuran masjid, pembinaan pengajian dasar Alquran, penerimaan dan penyaluran zakat pada umumnya masih ditangani oleh syara', demikian juga peringatan-peringatan hari-hari besar Islam, bahkan ada diantara aparat syara' juga berfungsi sebagai mubaliq.

Pengurusan jenazah, penyembelian hewan, memulai untuk mendirikan dan menaiki rumah baru, memimpin doa keselamatan, menuntun peziarah kekubur, yang masih menjadi tradisi masyarakat, diselenggarakan oleh aparat syara'.

Kalau kadhi berhalangan, biasanya dilimpahkan kepada imam atau aparat syara' lainnya, artinya harus dilaksanakan oleh syara. Masyarakat memandang syara' sebagai pemimpin dan panutan mereka, yang mampu menangani segala aktifitas keagamaan mereka.

Kenyataan yang ditemukan peneli, bahwa aparat syara' baik sebagai imam kelurahan, iamam dusun atau imam masjid, memangku jabatan tersebut terdorong oleh rasa pengabdian dengan menganggap pekerjaan syara' itu adalah 
pekerjaan mulia, karena langsung menyentuh kebutuhan spiritual masayarakat. Semangat pengabdian yang demikian mereka dalam mengembang amanat Allah. Kepercayaan masyarakat menjadi motivasi untuk bekerja lebih giat, Ikhlas dan menuntut ridha Allah semata, walaupun hasil yang diperoleh sangat minim.

Mereka berkeyakinan bahwa apabila pekerjaan sebagai syara' dilaksanakan dengan baik dan ikhlas, maka Allah akan memberikan rahmatNya di dunia dan di akhirat.

\section{SYARA' DAN GERAKAN KELU- ARGA BERENCANA.}

Tujuan gerakan keluarga berencana adalah **1) Menurunkan tingkat kelahiran, sebagai tujuan demogratis, dan 2) Membudayakan Norma Keluarga Kecil Bahagia dan Sejahtera (NKKBS), sebagai tujuan normatif.

Untuk mencapi tujuan tersebut, ditempuh berbagai langka, guna menyukseskan Gerakan Keluarga Berencan di Indonesia termasuk masyarakat pedesaan.

Umat Islam diharapkan menjadi pelopor, namun perlu juga memperhatikan ajaran agama yang berkaitan dengan Gerakan KB ini, guna menghindari kemungkinan-kemungkinan timbulnya berbagai ketegangan sosial sehingga menghambat jalannya gerakan $\mathrm{KB}$ ini. Masyarakat Banggae adalah penganut agama Islam yang patuh, maka pelaksanaan gerakan $\mathrm{KB}$ pada mulanya mendapat tantangan berat, petugas lapangan senantiasa mendapat hambatan bahkan ada yang nyaris korban.

Kerjasama yang dijalin antara petugas lapangan GKB dengan berbagai unsur, termasuk aparat syara', memberi petunjuk

bahwa Gerakan KB di kecamatan Banggae berjalan dengan baik dengan hasil yang memuaskan.

Data yang diperoleh peneliti menunjukkan adanya perhatian masyarakat terhadap Gerakan KB, sesuai keadaan tahun 1989, ternyata di kecamatan Banggae terdapat sejumlah 4.281 orang yang telah menjadi akseptor, dengan pemakaian alat kontrasepsi yang bervariasi, seperti berikut :

Keadaan Pemakai jenis alat kontrasepsi di Kecamatan Banggae, tahun 1989 adalah :

1. Pil KB

2. Kondom

3. Obat Vaginal

4. Tubektomi

5. Vasektomi

6. Suntikan

7. IUD

Jumlah

4.281 orang

Sumber : PLKB Kec. Banggae.

Dari Data tersebut ternyata akseptor yang menggunakan pil sangat menonjol dibanding alat kontrasepsi lainnya, menyusul suntikan, baru pemasangan spiral (IUD). Hal ini menunjukkan bahwa masyarakat Banggae yang sangat memegang ajaran agama dan tradisi budayanya, sangat hati-hati memilih alat kontrasepsi, karena senantiasa dihubungkan dengan hukum agama.

Diperoleh informasi dari imam, bahwa selain alat kontrasepsi yang secara formal digunakan masyarakat, ada juga yang menggunakan kontrasepsi spiritual berupa 
jimat, azal, dan semacamnya, disamping ada juga menggunakan sistim kalender.

\section{PERANAN SYARA' DALAM GERA- KAN KELUARGA BERENCANA}

Aparat Syara' sebagai lembaga agama di kecamatan Banggae,adalah panutan masyarakat dalam berbagai aspek kehidupan mereka. Sebagai panutan, segala tindak laku dan perbuatan mereka senantiasa mendapatkan perhatian masyarakat. Sesuatu yang masih dianggap masyarakat sebagai hal yang bam, tetapi telah dilaksanakan oleh aparat syara', maka masyaraka't akan menerima, mengikuti dan melaksanakannya. Akan h.:.lnya dengan Gerakan Keluarga Berencana ini, aparat syara' telah turut berpartisipasi aktif dalam pelaksanaannya, baik sebagai akseptor maupun sebagai penyuluh. Hal ini menggugah masyarakat untuk menjadi peserta aktif.

Penyuluhan Gerakan KB ini di kecamatan Banggae dilakukan minimal satu kali setiap triwulan oleh petugas lapangan dalam bentuk tim, dimana aparat syara' diikutsertakan, bukan hanya sebagai anggota, tetapi turut berperan aktif memberikan penyuluhan untuk mensukseskan program KB sebagai tugas nasional.

Aparat syara' disamping anggota tim yang dikoordinir oleh Petugas Lapangan KB, dengan kesadaran mereka, melakukan juga penyuluhan pada saat-saat mereka melakukan tugas syara' seperti pada upacara-upacara aqiqah, perkawinan, khitanan, selamatan, dan sebagainya yang dilakukan diluar tim.

Aparat syara' dalam kedudukannya sebagai tokoh yang masih tetap menjadi panutan, dalam keikutsertaan mereka berpartisipasi dalam gerakan keluarga, berencana, mempunyai arti yang patut dihargai, apalagi terhadap masyarakat yang kuat memegang Islam, seperti masyarakat di Kecamatan Banggae dan Kecamatan Pamboang.

Salah satu kenyataan pula, dari keberhasilan gerakan keluarga berencana ini, bahwa di Kecamatan Banggae sudah ada dua buah sekolah dasar yang menerima murid kelas satu dibawah jumlah minimal, sehingga tidak memenuhi syarat kelas yang diperlukan oleh sebuah sekolah.

Apabila keluarga berencana sukses maka kemungkinan besar sekolah dasar akan berkurang, sehingga guru dapat ditugaskan pada sekolah yang kekurangan tenaga guru, yang memungkinkan mutu pendidikan akan terwujud pula.

\section{PENUTUP}

Kesimpulan

1. Eksistensi Institusi syara di Kabupaten Majene, telah ada sejak Kerajaan Banggae menerima agama Islam menjadi agama Kerajaan, ketika Daeng Tamelanto, memegang tampuk Kerajaan.

2. Syara sebagai lembaga keagamaan, tetap berfungasi sejak zaman Kerajaan, zaman penjajahan, sampai pada zaman kemerdekaan, walaupun setelah kemerdekaan, tugas syara' sebahagian telah masuk dalam btdang tugas Departemen Agama.

Aparat Syara' yang terdiri dari imam' (kelurahan/desa, dusun atau imam masjid) serta para pembantunya, tetap dibutuhkan oleh masyarakat dalam melayani kegiatan spiritual keagamaan mereka, yang belum terjangkau oleh Departemen Agama, dengan menangani masalah-masalah keagamaan masyarakat, disamping menjadi panutan dan tempat menaruh harapan dalam semua aspek kehidupan keagamaan masyarakat 
Kecamatan Banggae khususnya, masyarakat Majene umumnya, yang masih kuat memegang ajaran Islam, dan tradisi adat dan keagamaannya.

3. Peranan aparat syara' dalam

Gerakan Keluarga Berencana di Kecamatan Banggae Kabupaten Majene, mempunyai arti penting, karena turut menentukan keberhasilan pelaksanaan gerakan keluarga berencana tersebut. Keikutsertaan dan partisipasi aktir aparat syara' dalam penyuluhan, pelayanan dan pelaksanaan gerakan keluarga berencana, mendukung masyarakat menerima dan mengikutinya tanpa adanya hambatan yang berarti.

\section{SARAN-S ARAN}

1. Syara' sebgai suatu institusi keagamaan, keberadaanya perlu dipertahankan terus, karena masih menjadi kebutuhan masyarakat, dalam memenuhi kehidupan keagamaan yang belum terjangkau oleh Departemen Agama, tetapi tetap dilaksanakan oleh aparat syara'

2. Imam dan para pembantunya sebagai aparat syara', perlu dipikirkan masa depan kehidupan rumah tangga mereka, sebagai imbalan atas pelayanan terhadap masyarakat, yang mereka lakukan tanpa pamrih.

Imbalan yang diberikan masyarakat kepada mereka, belum memadai, dibanding dengan luasnya bidang tugas yang diemban oleh mereka.

3. Keikutsertaan aparat syara' dalam gerakan keluarga berencana, baik dalam kegiatan penyuluhan dan pelayanan, maupun aktivitas lainnya yang berkaitan dengan gerakan keluarga berencana, agar senantiasa ditingkatkan kegiatannya demi suksesnya pelaksanaan gerakan keluarga berencana tersebut, sebagai suatu program nasional, demi kesejahteraan bangsa.

\section{DAFTAR KEPUSTAKAAN}

BPLK

Laporan Hasil Penelitian "Masuknya Islam di Sulawesi Selatan, Balai Penelitian Lektur Keagamaan, Ujung Pandang, $1985 / 1986$

BKKBN Membina Kemaslahatan Keluarga, Badan Koordinasi Keluarga Berencana Nasional, Jakarta 1982.

Koentjaraningrat, Manusia Dan Kebudayaan di Indonesia, Djambatan, Jakarta, 1987

Nazir, Moh. Ph. D. Metode Penelitian, Ghalia Indonesia, Jakarta, 1983

Saharuddin Mengenal pitu Bahana Binanga (Mandar) dalam Lintasan Sejarah Pemda Sulsel, C.V. Mallomo Karya Ujung Pandng, 1985

Sinrang, Andi Saipul Mengenal Mandar Sekilas Lintas, Ujung Pandang, t. th.

Tandilinting, dkk Ungkapan Tradisional yang ada kaitannya dengan Sila-sila dalam Pancasila, Propinsi Sulsel, Depdik-bud, Ujung Pandang, 1984.

Tuande Maricar Sahid, Makala "Islam DR. H. dan Keluarga Berencana, LKKNU, Ujung Pandang, 1990. 